\title{
Előrejelzési módszerek elemzése és összehasonlítása egy kisvállalat számára
}

\section{Analysis and Comparison of Forecast Methods for a Small Enterprise}

\author{
L, TÖRŐ ${ }^{1}$, L. PUSZTAI ${ }^{2}$ \\ ${ }^{1}$ Debreceni Egyetem, Múszaki Kar, Múszaki Menedzsment és Vállalkozási Tanszék, lilla.creatoro@gmail.com \\ ${ }^{2}$ Debreceni Egyetem, Műszaki Kar, Műszaki Menedzsment és Vállalkozási Tanszék, pusztai.laszlo@eng.unideb.hu
}

Absztrakt. Az elörejelzési módszerek alkalmazása alapvető elem egy vállalat hosszútávú nyereséges müködéséhez, amelyre jellemzốen nem fordítanak kellő figyelmet a cégek. A kutatásban egy esettanulmányon keresztül mutatjuk be egy kereskedelemmel foglalkozó vállalat előrejelzését. Célunk a kutatás során egy olyan módszer megtalálása volt, amellyel pontosabban számíthatóvá, elôrejelezhetővé válik a jövőben várható kereslet a cég termékei iránt, és így átgondoltabb készletgazdálkodási stratégiát kiválasztva csökkenhet a vállalat költsége. Hét különböző modellt vizsgáltunk: mozgó átlagos, és súlyozott mozgó átlagos előrejelzést különböző tagszámmal, illetve exponenciális simítást. A négytagú súlyozott mozgó átlagos előrejelzés bizonyult a legpontosabbnak, ezt követőjellel vizsgálva is helyesnek találtuk.

Abstract. The application of forecasting models is an essential part of the profitable operations of every company. However, today's small and medium sized enterprises (SMEs) does not pay enough attention to this field. This research presents a case study in which we tried to determine the sequence of a forecasting process, furthermore, determine the best applicable method to the dataset. Seven dissimilar forecasting method was applied: moving average and weighted moving averages with different periods (2-3-4 weeks), as well as exponential smoothing. The four-weeklong weighted moving average served the best solution, which was tested by tracking signal as well.

\section{Bevezetés}

Minden vállalat alapvető célja a vevő igények felkutatása, és azok minél magasabb szinten történő kielégítése, hiszen csak így érhet el profitot működése során. Azonban ez a folyamat - főleg, ha a piacon erős konkurensekkel kell felvennie a versenyt - rendkívül összetett, és nagyon precíz és alapos tervezést igényel. A logisztika $9 \mathrm{M}$-je fogalmazza meg mindazt, ami szükséges ahhoz, hogy a vevő elégedett legyen a cég által nyújtott termékkel és/vagy szolgáltatással: a megfelelő információ, a megfelelő anyag, a megfelelő energia, a megfelelő személyek jussanak el, a megfelelő mennyiségben, a megfelelő minőségben, a megfelelő időpontban, a megfelelő helyre, a megfelelő költséggel. Ehhez magas színvonalú termelésmenedzsment szükséges, aminek elengedhetetlen része a pontos előrejelzés, kapacitáselemzés, és ennek megfelelő készletgazdálkodás. 


\section{Szakirodalmi áttekintés}

\subsection{Előrejelzés}

\subsubsection{Az elörejelzés szerepe egy vállalat életében}

Az előrejelzés a vásárlói igények jövőbeni alakulásának megjóslása, legyen szó akár termékről, vagy szolgáltatásról. Célja, hogy a vállalat fel tudjon készülni a beérkező megrendelésekre, hiszen a termelésmenedzsment az igényekhez alakítja a termelő kapacitásokat, a szükséges alapanyag- és munkaerő mennyiséget. Segítségével felmérhetjük, és ütemezhetjük a várható költségeket, elkerülhetjük a felesleges készlet felhalmozását, valamint az esetleges hiány kialakulását is csökkenthetjük [1]. Ezért nélkülözhetetlen elem a készletgazdálkodásban is. Természetesen egyik előrejelzési módszer sem lehet tökéletesen pontos, viszont egy jól megválasztott előrejelzési stratégia jelentős mértékben növelheti a termelés hatékonyságát, illetve csökkentheti a költségeket. [2]

A vevői igénynek több komponensét különbözteti meg a szakirodalom, amelyek segíthetnek beazonosítani az adatsor mintázatát: az első a konstans, vagyis állandó igény, amely körül a vizsgált időszakban a kereslet ingadozhat [3]. Az idősorban előfordulhat trendelem, amely az idő előrehaladtával szisztematikus változást, monoton csökkenést vagy növekedést jelent [4]. Szezonalitás is szerepet játszhat a megrendelések számának változásában, ez összefügghet pl. az évszakok váltakozásával, illetve a véletlen szerepéről sem feledkezhetünk meg [1]. Mivel számos tényező befolyásolja az igény alakulását, ezért érdemes mindig több lehetőséget is figyelembe venni, tehát a tervidőszakra párhuzamosan több előrejelzési módszert is alkalmazni, mivel minden módszer más-más összetevőket, vagy más súllyal vesz figyelembe [2]. A megfelelően pontos előrejelzés nagymértékben javítja a vevői kiszolgálás színvonalát, hiszen a jól ütemezett gyártásnak köszönhetően gyorsul a megrendelések feldolgozása, és ritkán lép fel jelentős készlethiány. [3]

\subsubsection{Előrejelzések csoportosítása}

Kereslet előrejelzésére számos módszer áll rendelkezésre, melyek közül azokat érdemes kiválasztani, amelyekhez elegendő adatunk van, valamint a legjobb értéket szolgáltatja számunkra [1]. Az első nagy csoportot képző kategória a rendelkezésre álló adatok minőségére utal. Ezen belül megkülönböztethetünk minőségi (kvalitatív) valamint mennyiségi (kvantitatív) technikákat. Kvalitatív módszereket általában akkor alkalmazunk, ha nem állnak rendelkezésünkre múltbéli adatok a vevő igényről, és annak változásáról, valamint ha ezek az adatok nem megfelelőek ahhoz, hogy egy előrejelzés alapját alkossák. Emiatt szakértői becslésre, csoportmunkára, esetleg történelmi analógiára kell hagyatkoznunk. Kvantitatív módszerek: Ezeket akkor használjuk, ha visszamenőleg vizsgálni tudjuk az igény alakulását. Az adatok jellegétől függően tovább tudjuk csoportosítani a kvantitatív módszereket [4]:

- Kauzális módszerek: Az igény alakulását valamilyen külső tényező változása (pl. időjárás, stb.) befolyásolja, és ennek a változónak a megfigyelésével alkotunk előrejelzést. Fontos valamilyen 
viszonylag állandó összefüggést megállapítani az igény oka és az igény között, hogy elég pontos legyen az előrejelzés.[1]

- Projektív módszerek: Matematikai modellekkel számoljuk az igény jövőben várható nagyságát, a modell kiválasztásánál fontos figyelembe vennünk, hogy van-e valamilyen trendvonal az igényben. [7]

- Stacionárius modellek: Amennyiben nem tartalmaz trendet az igény, ilyet használunk, ezek a legegyszerűbb modellek.[4][7]

- Trend modellek: Az igényben megfigyelhető trendet figyelembe véve készítünk előrejelzést. [4][7]

\subsubsection{Előrejelzések értékelése}

A kvantitatív, ezen belül is a projektív módszerek alkalmazása során külön eredményeket kaphatunk előrejelzéskén. Rövid távú tervezés esetén ki kell találnunk, melyik módszer szolgáltatja a legjobb értékeket. Ezen módszerek közül léteznek olyan mutatók, amelyek csupán egy időszak pontosságát mutatja meg (pl. előrejelzés hibája), tudunk relatív hibát számolni, azonban ezek nincsenek segítségünkre az értékelés során. A termelésmenedzsmentben alkalmazott átlagos négyzetes hiba (Mean Squared Error - MSE) mutató azonban teljeskörűen megmutatja, hogy mennyivel térünk el a tényleges igényhez képest, akár több időszakot felölelően [1][3]. Ennek a módszernek az egyik nagy előnye, hogy büntetőleg hat egy nagyobb hiba megléte az előrejelzésben, továbbá a mutató gyöke felhasználható további készletgazdálkodási mutatók meghatározásához, mint például a biztonsági készletszint. [3]

$$
M S E=\frac{\sum\left(E_{t}\right)^{2}}{n}
$$

Ahol: $E_{t}=$ Előrejelzés hibája t-ik időszakban

$n$ = időszakok száma

További módszerként ismeretes a követőjel, amelyet az előrejelzésünkre illeszthetünk. Ezen módszer megmutatja számunkra, hogy az tényleges és előrejelzett igények közötti eltérés a módszer vagy a véletlen műve-e. A mutatóhoz alsó- és felsőhatár meghatározás is társul, így a kiugró értékkel rendelkező modellek elvetésre kerülnek a végső értékelésnél [4][5].

\section{Anyag és módszer}

\subsection{A vizsgált vállalat bemutatása}

A cég egy magyar kisvállalat, ami 2010 óta foglalkozik a vizsgált termékek forgalmazásával. Emellett projektek kivitelezésével is foglalkoznak, melyek során természetesen a termékeket is alkalmazzák. Hét termékkel foglalkoznak, ezek közül kettőt az Amerikai Egyesül Államokból importálnak, tehát a készletgazdálkodás során kiemelt figyelmet igényel a megfelelő raktárkészlet fenntartása a hosszú és 
költséges szállítás miatt. Az elmúlt évek során egyre bővült a cég, folyamatosan nő a megrendelések mértéke és száma is, szezontól függően összesen 7-10 fővel dolgoznak.

\subsection{Problémafelvetés, a kutatás célkitűzései}

Ahogy a fentiekben olvasható, a logisztikai folyamatok jelentős szervezést igényelnek a termékek egy része beszerzésének hosszú teljes átfutási ideje miatt. Eddig a vállalat nem foglalkozott az igény előrejelzésének kalkulálásával, viszont a menedzsment szerint jelentősen javulhatna a vevőkiszolgálás színvonala, illetve a költségek is csökkenthetők lennének előrejelzési módszerek alkalmazásával.

A kutatási célkitűzésünk az előrejelzési módszerek különböző indikátorokkal történő összevetése, a legjobb módszer megtalálása, melyet a vállalat a jövőben akár hosszútávon is eredményesen, és hatékonyan tud alkalmazni, ezzel javítva, illetve gyorsítva a logisztikai folyamatok menetét.

\subsection{Kutatás lépései}

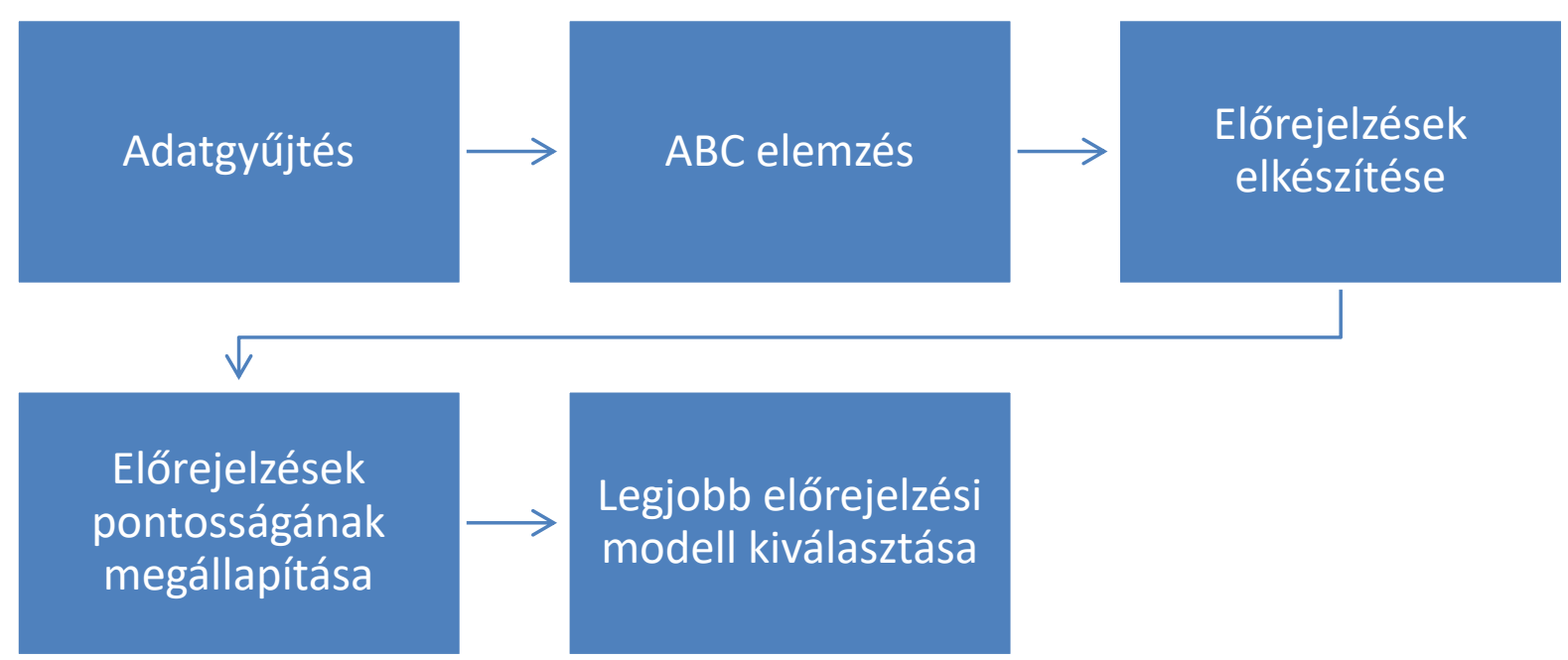

1. ábra. A kutatás folyamatábrája (forrás: saját kutatás)

A kutatás adatgyűjtéssel kezdődött, amelyet a vállalat számítógépes ügyviteli rendszerben végeztünk, innen kiimportáltuk 2017-es és 2018-as években megrendelt mennyiséget a vizsgált termékekből. Ezt követően a kinyert adatokból egy ABC elemzést készítettünk. Az elemzés eredményeként kapott 2 "A" kategóriás termék közül a cég prioritása alapján a 2-es termékre készítettünk el hét különböző előrejelzést. Az előrejelzések számítása során az egyes súlyok és simítóparaméterek értéke nem szakértői becslés útján került megítélésre, hanem az átlagos négyzetes hiba (Mean Squared Error - MSE) célfüggvénye alapján optimalizáltuk ezen értékeket. A kapott előrejelzési eredményeket indikátorok segítségével elemeztük, megállapították az előrejelzési modellek pontosságát, és a kapott mutatók alapján kiválasztottuk a legkedvezőbbet. Ezt végül követőjellel is megvizsgáltuk, hogy megbizonyosodjunk a modell helyességéről, és hosszú távon való használhatóságáról. 


\section{Eredmények és azok értékelése}

A munka során Microsoft Excelben dolgoztunk, melynek Solver bővítményét is alkalmaztuk az előrejelzési módszereknél. Első lépésként a termékek kategorizálásához ABC elemzést végeztünk, ami fontos ahhoz, hogy meg tudjuk állapítani, melyik termék/termékcsoport a leghangsúlyosabb a cég által forgalmazott termékek közül. Az elemzés eredményei a következő diagrammon (2. ábra) láthatók:

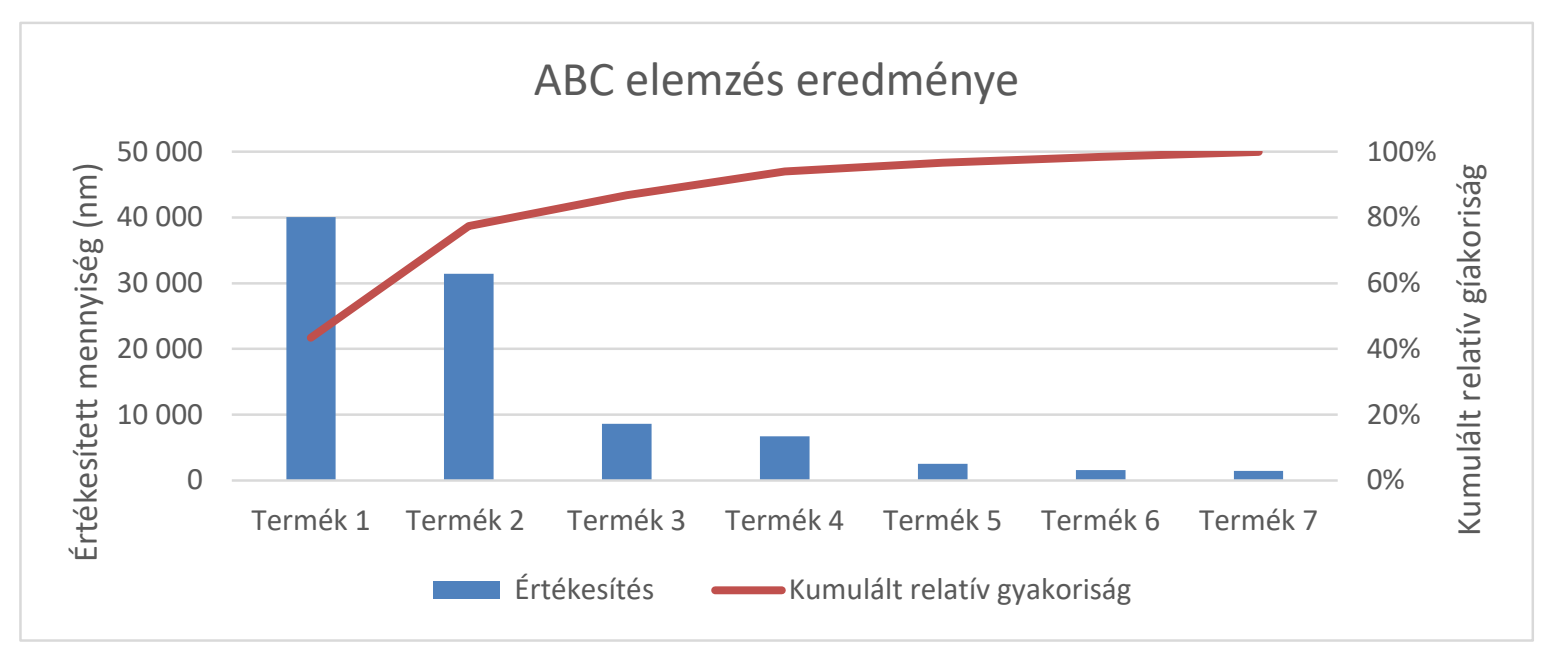

2. ábra. ABC elemzés eredménye. (forrás: saját kutatás)

A termékeket kumulált relatív gyakoriság alapján sorba rendezve alakítottuk ki a kategóriákat, az első két termék került az " $A$ " kategóriába, ezek az értékesített négyzetméter 77,46\%-át teszik ki. A következő 16,55\%-ot a két “B” kategóriás termék jelenti, az utolsó 5,99\%-ot pedig a maradék 3 termék adja, amik a “C" kategóriába kerültek. A vállalat vezetésével való egyeztetést követően az előrejelzést csak az egyik "A" kategóriás termékre számoltunk, hiszen elmondásuk szerint ennek a terméknek a legfontosabb a várható kereslete a hosszú átfutási idő miatt. Az elemzés alapja a Pareto-elv, ez a vizsgált termékeknél is jól láthatóan érvényesül, hiszen a 28\%-uk adja az igény több, mint 77\%-át. Tehát az erőforrások csoportosításánál mindenképp az A kategóriás termékekre kell a legnagyobb hangsúlyt fektetni, hogy a ráfordítások és az eredmények aránya optimális legyen.

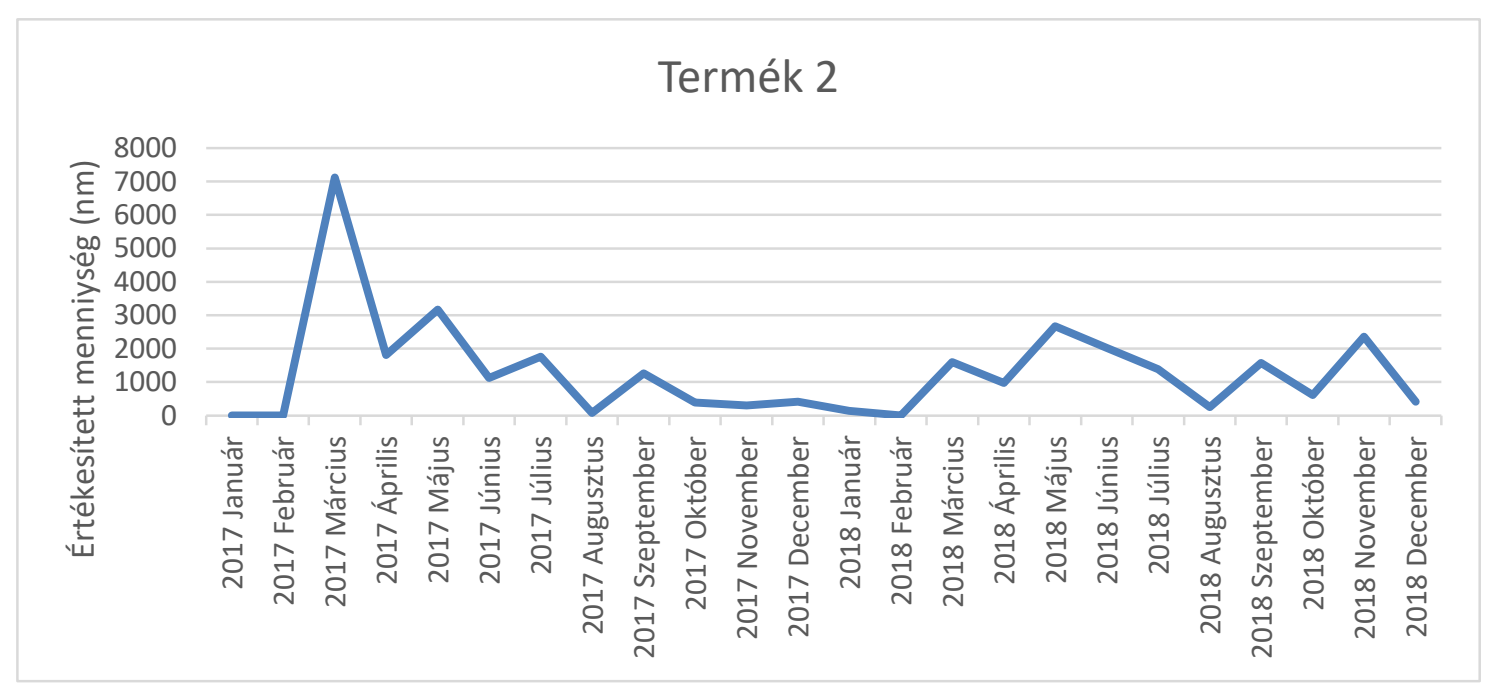

3. ábra. Termék 2 igények 2017-18-ban (forrás: saját kutatás) 
A termékre való keresletet visszamenőleg két évre vizsgáltuk meg, ez a következő diagramon (3. ábra) látható:

Az igényben enyhe csökkenő trend figyelhető meg, ezt azonban csupán egyetlen, a többi hónaptól szignifikánsan magasabb megrendelés okozza 2017 márciusában. Ezen kívül összességében csak szezonalitást figyelhetünk meg az évszakok változása következtében. Mivel a vállalat fel van készülve megfelelő mennyiségű alapkészlettel egy-egy ilyen nagyobb léptékű megrendelésre, ezért nem számoltunk trenddel. A módszereket ennek megfelelően választottuk meg, stacionárius modelleket használtunk: mozgó átlagos előrejelzést (2,3, és 4 taggal), súlyozott mozgó átlagos előrejelzést (2,3, és 4 taggal), és exponenciális simítást.

A súlyozott mozgó átlagos előrejelzés esetén a súlyokat nem szakértői becsléssel adtuk meg, hanem a Solvert alkalmazva számítottuk ki őket, a következő célfüggvény:

$$
0 \leq w_{1}, w_{2}, \ldots, w_{n} \leq 1
$$

és korlátozó tényező segítségével:

$$
\operatorname{Min} z=\frac{\sum_{i=1}^{n}\left(e_{t}\right)^{2}}{n}
$$

$\mathrm{Az}$ exponenciális simításnál is a Solver segítségével dolgoztunk, az alfa simító paraméter meghatározásának célfüggvénye a következő volt:

$$
\operatorname{Min} z=\frac{\sum_{i=1}^{n}\left(e_{t}\right)^{2}}{n}
$$

A korlátozó tényező pedig a súlyok számításához hasonlóan:

$$
0 \leq \alpha \leq 1
$$

Minden módszernél eltérő eredményt kaptunk, azonban a kéttagú mozgó átlagos előrejelzés MA(2), és a kéttagú súlyozott mozgó átlagos előrejelzés WMA(2) eredménye nagyon közel áll egymáshoz. Ez annak köszönhető, hogy a Solver által számított súlyok 0,48 és 0,52 voltak, tehát közel azonos aránnyal szerepelt a legutolsó és az azt megelőző érték a képletben.

Az előrejelzések pontosságát különböző indikátorokkal vizsgáltuk; elsőként az átlagos négyzetes eltérést (MSE) számítottuk, majd ennek négyzetgyökét véve az RMSE-t állapítottuk meg. Ez az illeszkedés számolásához szükséges, ugyanis azt az átlagos eltérés négyzetének gyöke, és az átlag hányadosaként kapjuk meg. Ez a mutató nagyon szemléletesen, százalékos formában jelzi számunkra, hogy mennyire pontos az előrejelzésünk (minél közelebb van a 0-hoz, annál jobban illeszkedik a modell a tényleges adatsorra).

A legpontosabb eredményt a súlyozott négytagú mozgó átlagos előrejelzés WMA(4) adta, ennek lett a legalacsonyabb MSE értéke, tehát a jelenlegi körülmények között ez a legjobb módszer a cég számára a 
jövőben várható kereslet felbecsüléséhez. Emellett a kéttagú mozgó átlagos előrejelzés, és a kéttagú súlyozott mozgó átlagos előrejelzés eredményei is megközelítik a WMA(4)-ét.

Az összes módszer összehasonlítását a következő táblázatról olvashatjuk le, a módszerek között viszonylag kis eltérés mutatkozik (1. táblázat):

\begin{tabular}{|c|c|c|c|c|c|c|c|}
\hline & MA(2) & MA(3) & MA(4) & WMA(2) & WMA(3) & WMA(4) & Exp. Simítás \\
\hline MSE & 848811,84 & 1300477,71 & 1189496,51 & 847162,08 & 847162,08 & 783058,53 & 910719,98 \\
\hline RMSE & 921,31 & 1140,38 & 1090,64 & 920,41 & 920,41 & 884,91 & 954,32 \\
\hline Átlag & 1310 & 1310 & 1310 & 1310 & 1310 & 1310 & 1310 \\
\hline $\begin{array}{c}\text { Illeszkedés } \\
\text { RMSE / } \\
\text { Átlag) }\end{array}$ & $70,33 \%$ & $87,05 \%$ & $83,25 \%$ & $70,26 \%$ & $70,26 \%$ & $67,55 \%$ & $72,85 \%$ \\
\hline
\end{tabular}

1. táblázat. Előrejelzések hibaindikátorainak összehasonlítása (forrás: saját kutatás)

A négytagú súlyozott mozgó átlagos előrejelzést - mivel az bizonyult a legpontosabbnak - követőjellel is megvizsgáltuk, ezt a következő diagramon láthatjuk (3. ábra):

\section{Követőjel a 4-tagú súlyozott mozgóátlagra}

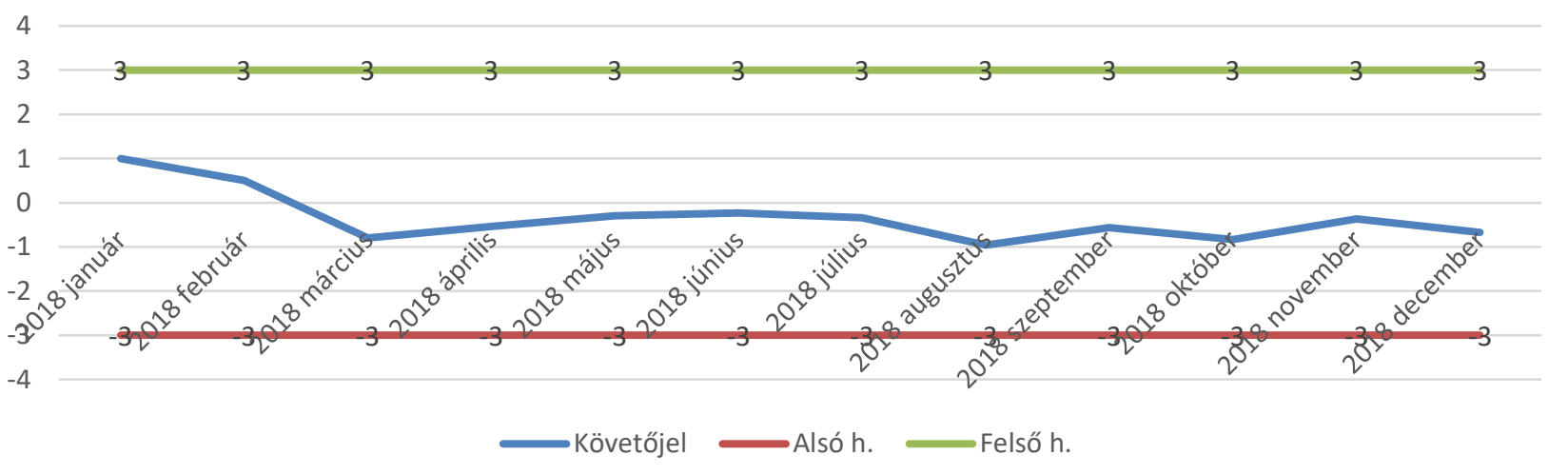

4. ábra. Követôjel a négytagú súlyozott mozgó átlagra (forrás: saját kutatás)

A követőjel kiválóan alkalmas arra, hogy megvizsgáljuk, mennyire helyes az általunk kiválasztott módszer az igények előrejelzésére. Hiszen abban az esetben, amikor a követőjel átlépi a korlátokat, már nem az igény szórása jelenti a problémát, hanem az előrejelzési modellt választottuk meg rosszul az adott adatokhoz. A követőjelben nem lelhető fel szisztematikus változás az idő előrehaladtával, valamint a megadott határokon se lép túl. A 4. ábrán látható követőjel értéke megfelelő, így a kiválasztott négy tagú súlyozott mozgóátlag helyesnek mondott, használata ajánlott a vállalat számára. 


\section{4. Összegzés}

A kiindulópontunk az volt, hogy a vállalat a korábbiakban nem alkalmazott előrejelzési módszereket, ez adta a kutatásunk alapját, célunk egy hosszútávon, eredményesen és hatékonyan működő előrejelzési módszer megtalálása volt. Összesen hét változatban használtunk mozgó és súlyozott mozgó átlagos előrejelzést, illetve exponenciális simítást, ezekhez a Microsoft Excel Solver bővítményét használtuk. A négytagú súlyozott mozgó átlagos előrejelzés bizonyult a legpontosabbnak, ennek helyességét követőjellel is igazoltuk. A kutatást behatárolta, hogy csupán két évre visszamenőleg rendelkeztünk adatokkal, viszont a cég már közel tíz éve működik. Ezenkívül, források hiányában nem foglalkoztunk komplexebb előrejelzési modellekkel, a továbbiakban még ezekkel tovább lehet folytatni a kutatást.

\section{Hivatkozások}

[1] Koltai Tamás (2006): Termelésmenedzsment, Typotex Kiadó

[2] Oláh et al. (2017): A készlettervezés és az elörejelzési modellek kapcsolata, Acta Carolus Robertus

[3] Render, B. - Heizer, J. (1996): Principles of operations management. NJ: Prentice Hall.

[4] Russsel, S. R. - Taylor, W. B. (2011): Operations Management. John Wiley and Sons Inc.

[5] Dobos I. - Gelei A. (2015): Biztonsági készletek megállapítása elörejelzés alapján. Vezetéstudomány. XLVI. évf. 4

[6] Cliff T. Ragsdale: Spreadsheet modelling and decision analysis. Thomson-South Western 2007 